\title{
\begin{tabular}{|l|l|}
\hline JURNAL EKONOMI DAN MANAJEMEN \\
\hline
\end{tabular} \\ P-ISSN: 2598-9022/ E-ISSN: 2598-9618 \\ Available at: http://e-journal.unipma.ac.id/index.php/capital
}

\section{Pengaruh Brand Respect Terhadap Lovemark Pada Produk Smartphone Asal China}

\author{
Ali Wardhana ${ }^{1}$, Pipiyen ${ }^{2)}$ \\ ${ }^{1}$ Fakultas Ilmu Sosial dan Humaniora, Universitas Bunda Mulia \\ email: awardhana@bundamulia.ac.id \\ Fakultas Ilmu Sosial dan Humaniora, Universitas Bunda Mulia \\ email: piyensu00@gmail.com
}

\begin{abstract}
Indonesia as a country that has smartphone sales growth that continues to grow and become the main and most developed market. To become the smartphone market leader, it needs Lovemark, loyalty beyond reason. This happened to 2 smartphone brands from China, Xiaomi and Vivo. This research looks at how the lovemark on the Xiaomi and Vivo brands is built through brand respect and has an impact on positive WOM and repurchase intentions. The results of this study indicate that in the Xiaomi and Vivo brand performance, brand reputation and brand trust have a positive impact on brand respect and ultimately make impact at lovemark. In addition, this study also found that lovemark has a positive impact on positive WOM and repurchase intentions. In the future research can be applied to the brands that slowing sales
\end{abstract}

Keyword : brand performance; brand reputation; brand trust; brand respect; lovemark

Abstrak

Indonesia sebagai negara yang memiliki pertumbuhan penjualan smartphone yang terus bertumbuh dan menjadi pasar utama dan paling cerah. Untuk memenangkan pasar smartphone diperlukan lovemark, loyalitas yang melampaui alasan. Hal tersebut diduga terjadi pada 2 merek smartphone asal china, yaitu merek Xiaomi dan Vivo. Penelitian ini bertujuan melihat bagaimana lovemark pada merek Xiaomi dan Vivo dibangun melalui brand respect dan berimbas pada positif WOM dan niat pemebelian Ulang. Hasil penelitian ini menunjukan bahwa pada merek Xiaomi dan Vivo kinerja merek (brand performance), reputasi merek (brand reputation) dan kepercayaan merek (brand trust) memberi dampak positif terhadap brand respect dan pada akhirnya brand respect berpengaruh pada lovemark. Pada penelitian dimasa yang akan datang dapat diimplementasikan pada brand yang mengalami penurunan

Kata kunci : brand performance, brand reputation, brand trust, brand respect, lovemark

\section{A. PENDAHULUAN}

Dewasa ini inovasi terhadap produk teknologi, khususnya produk smartphone atau yang lebih dikenal dengan telepon pintar berkembang begitu cepat. Setiap pabrikan berlomba-lomba untuk melakukan berbagai inovasi dan mengeluarkan produk, sehingga pasar dibanjiri oleh berbagai produk telepon pintar yang serupa dan berdampak pada penjualan berbagai perusahaan penyedia telepon pintar. Lembaga riset dan konsultan, Gartner, mengungkapkan bahwa pada kuartal ke 4 tahun 2018 penjualan global telpon 
pintar mengalami perlambatan pada permintaan untuk smartphone high-end sedangkan pada telepon pintar kelas menengah kebawah tetap kuat di seluruh pasar (Egham, 2019)

Lebih lanjut lembaga tersebut mengungkapkan bahwa melambatnya inovasi pada telepon pintar kelas atas ditambah dengan kenaikan harga, menghalangi keputusan pengganti untuk ponsel cerdas kelas atas. Hal tersebut tercemin pada penurunan pangsa pasar merek Apple pada kuartal 4 tahun 2017 sebesar 17,9\% menjadi 15,8\% pada kuartal 4 tahun 2018 sedangkan pada 3 raksasa asal china yaitu Huawei, Oppo dan Xiaomi mengalami kenaikan.Hal serupa juga terjadi pada negara di kawasan asia pasifik, khususnya di Indonesia yang merupakan pasar smartphone yang terus bertumbuh dan menjadi pasar yang utama dan yang paling cerah (Alto, 2019). Kendati persaingan antara produsen telepon pintar meningkat drastis, sebuah analisa yang diterbitkan oleh canalys menunjukan sampai kuartal ke 42018 pasar smartphone Indonesia dikuasai oleh merk Samsung dengan pangsa pasar sebesar 25,4\% (Alto, 2019). Jika melihat lebih lanjut, maka akan terlihat secara year on year pertumbuhan merek Samsung yang mencapai 21,5\% sedangkan pada merek xiaomi bertumbuh sebesar 139,4\% dan vivo bertumbuh dalam 132\% (Alto, 2019). Hal tersebut menujukan bahwa posisi Samsung yang cukup rawan dan bukan tidak mungkin pada tahun yang akan datang pangsa pasar smartphone di Indonesia akan dikuasai oleh xiaomi dan vivo. Namun satu hal yang menarik adalah walaupun penjualan global mengalami penurunan, namun justru di Indonesia xiaomi mengalami kenaikan yang cukup signifikan, bahkan xiaomi menduduki peringkat kedua dalam pangsa pasar telepon pintar setelah Samsung. Hal ini dapat menjadi salah satu indikasi bahwa telepon pintar keluaran china sudah mendapat kepercayaan dari masyarakat Indonesia.

Tabel 1 : Penjualan Smartphone Di Indonesia Kuartal 4 tahun 2018

\begin{tabular}{ccc}
\multirow{2}{*}{ Penyedia Telpon Pintar } & \multicolumn{2}{c}{ Kuartal 4 Tahun 2018 } \\
\cline { 2 - 3 } & Market Share (\%) & Year on year growth (\%) \\
\hline Samsung & 25,4 & $+21,5$ \\
\hline Xiaomi & 20,5 & $+139,4$ \\
\hline Oppo & 19,5 & $+0,8$ \\
\hline Vivo & 15,9 & +132 \\
\hline Advan & 4,1 & -25
\end{tabular}

Sumber :https://www.canalys.com/newsroom/samsung-leads-in-indonesian-smartphones-as-marketsurges-ahead-to-close-2018-up-171

Kenaikan pangsa pasar tersebut patut diduga akibat kenaikan niat beli pada konsumen baru dan niat pembelian ulang pada konsumen lama untuk merek Xiaomi dan Vivo.

44 | C A P I T A L, V O L U M 4, NOMOR 1, S E P T EM B E R 2020 
Pada niat beli, fitur produk dan pengaruh sosial memiliki korelasi yang positif dan signifikan, dimana fitur produk didefinisikan sebagai atribut yang dapat memuaskan konsumen bila membeli sebuah produk sedangkan pengaruh sosial merupakan saran dan opini dari lingkungan sekitar (Rahim, 2016). Senada dengan penelitian tersebut, fitur produk yang bagus dengan harga yang lebih terjangkau memang menjadi ciri khas telpon pintar asal china seperti Xiaomi dan Vivo, sehingga tidak mengherankan merek tersebut lebih terjangkau bagi sebagian masyarakat Indonesia. Faktor yang ikut mempengaruhi niat beli adalah pengaruh sosial yang serupa dengan sosial elektronik word of mouth (eWOM) dimana eWOM memiliki hubungan positif dan signifikan dengan niat beli (Chetna dan Kumar, 2017). Kedua faktor yang mempengaruhi diatas, memberi dampak pada niat beli konsumen baru, namun pada niat pembelian ulang belum terdapat penelitian. Belum banyak literatur mengenai niat pembelian ulang pada telepon pintar asal China yang sedang mengalami kenaikan yang cepat dan memiliki pangsa pasar yang cukup besar juga ikut mendorong penelitian ini dengan mengunakan konsep serupa.

Penelitian ini menggunakan konsep brand performance yang dirasa sesuai mengingat smartphone asal China dikenal dengan harga yang murah dan kehandalan produk. Bila suatu merek menghasilkan kinerja yang baik (brand performance) akan menghasilkan rasa percaya (brand trust) dan reputasi yang positif (brand reputation) (Giovanis dan Athanasopoulou, 2018).Oleh karena itu, penelitian ini melihat dampak brand respect yang terdiri dari tiga elemen, yaitu brand performance, brand reputation dan brand trust terhadap lovemark yang bermanifestasi dalam niat pembelian ulang (repurchase intention) dan positif word of mouth. Tujuan dari penelitian ini adalah untuk berkontribusi untuk mendukung penelitian terdahulu dengan sampel yang beda dan variabel yang tereliminasi. Penelitian ini juga mempunyai tujuan untuk mengetahui lovemark yang dijelaskan dengan oleh brand respect.

\section{B. TINJAUAN PUSTAKA}

Penelitian ini merujuk pada penelitian Apostolos dan Pinelopi (2018) tentang dampak brand performance, brand reputation dan brand trust terhadap lovemark yang bermanifestasi dalam niat pembelian ulang (repurchase intention) dan positif WOM

Lovemark diyakini akan menjadi merek dan bisnis yang menciptakan hubungan emosional yang tulus dimana rasa hormat (respect) menjadi salah satu prinsip dasarnya 
(Robert, 2005). Rasa hormat tersebut nampak pada brand respect yang pada penelitian ini menjadi fondasi dan penjelas dari lovemark. Brand respect sendiri dipengaruhi oleh 3 hal yaitu, kinerja yang baik (brand performance), reputasi merek (brand reputation), kepercayaan merek (brand trust). Menurut Hawas (2013) reputasi merek (brand reputation) didefinisikan sebagai penelusuran menurut pendapat pelanggan mengenai keandalan dan kompetensi suatu produk sedangkan, kepercayaan merek (brand trust) didefinisikan sebagai kemauan konsumen rata-rata untuk mengandalkan kemampuan merek untuk melakukan fungsi yang dinyatakannya. Kepercayaan merek (brand trust) merupakan faktor kunci membangun hubungan jangka panjang antara perusahaan dan konsumennya karena jika konsumen mempercayai perusahaan yang memberikan nilai tinggi pada produk/jasa, maka dia akan lebih mungkin mengembangkan beberapa bentuk niat perilaku positif terhadap perusahaan ini (Yang dan Liu, 2018).

H1 = Kinerja merek (brand performance), reputasi merek (brand reputation), kepercayaan merek (brand trust) berpengaruh pada brand respect

$\mathrm{H} 2$ = Brand respect berpengaruh pada Lovemark

Word of mouth merupakan salah satu konsep yang banyak digunakan dalam berbagai literlatur pemasaran karena konsep ini dapat menjadi salah satu manifestasi dari loyalitas merek bila dilihat dari sudut pandang sikap.Penelitian terdahulu mengungkapkan bahwa word of mouth sebagai salah satu cara yang memiliki efek paling besar pada orang dan membujuk orang untuk membeli produk atau jasa lebih dari iklan lainnya karena biasanya orang mempercayai apa yang mereka dengar langsung dari orang lain (Maisam dan Mahsa 2016). Terdapat 2 kategori word of mouth(WOM) yaitu positif WOM dan negatif WOM dimana positif word of mouth memberi dampak yang lebih daripada negatif word of mouth (East et al, 2017). Lebih lanjut dikatakan bahwa orang akanlebih terbuka untuk dipengaruhidan berespon lebih terhadap positif WOM (East et al, 2017). Positif WOM juga mampu mengurangi dampak selama tahap evaluasi siklus pembelian konsumen atau dengan kata lain dapat menjadi peredam risiko utama terkait risiko kinerja dan keuangan suatu produk (Sweeney et al, 2008).

Niat pembelian ulang seringkali erat kaitannya dengan kepuasan konsumen. Hal tersebut dikarenakan penentu utama dari niat pembelian kembali adalah kepuasan atau ketidakpuasan yang dianggap sebagai hasil dari konfirmasi atau diskonfirmasi harapan sebelumnya mengenai kinerja produk (Filieri, 2017). Lebih lanjut dalam penelitian 
Filieri (2017) niat pembelian ulang akan mengikuti keputusan awal (penerimaan atau pembelian dan dipengaruhi oleh pengalaman penggunaan awal. Definisi niat pembelian ulang dinyatakan sebagai keinginan pelanggan untuk membeli secara terus-menerus dari perusahaan atau perusahaan (Ahmad et al, 2016) dan akan mengacu pada probabilitas subjektif konsumen untuk melakukan patronisasi ulang (Wu et al, 2014).
H3 = Lovemark berpengaruh pada positif word of mouth dan niat pembelian ulang (repurchase intention)

Pada penelitian terdahulu menggunakan 2 dimensi utama yaitu brand respect dan brand love, namun pada penelitian ini berfokus pada brand respect karena sub dimensi dari brand respect yaitu kualitas merek (brand quality), reputasi merek (brand reputation), kepercayaan merek (brand trust) dirasa lebih relevan pada produk asal China dimana merek asal china dikenal harga yang murah dengan kualitas yang baik. Alasan tersebut juga yang mengeliminasi salah satu manifestasi loyalitas yaitu kesediaan untuk membayar lebih mahal (pay price premium). Dengan demikian terdapat 2 variabel yang dieliminasi yaitu dimensi kedua brand dan kesediaan untuk membayar lebih mahal (pay price premium), sehingga kerangka penelitian ini sebagai berikut:

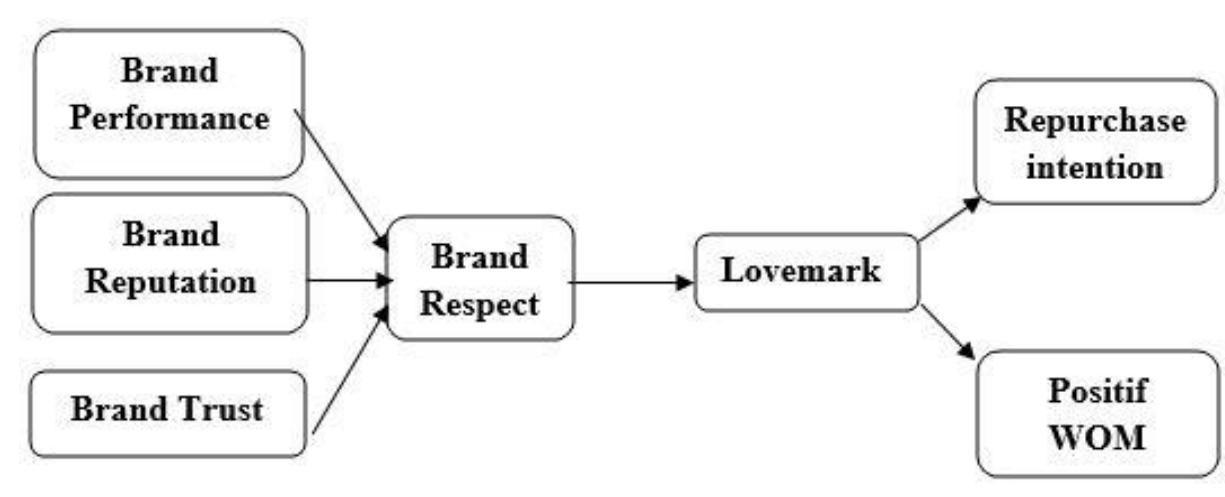

Gambar 1 : Model Hipotesa

Sumber: Apostolos dan Pinelopi (2018) dengan pengurangan variabel

\section{METODE PENELITIAN}

Penelitian ini menggunakan sampel pada satu titik waktu tertentu sehingga penelitian ini merupakan penelitian cross sectional (Leavy, 2017). Jumlah sampel yang digunakan merujuk pada Sekaran dan Bougie (2016) yang menyarankan ukuran sampel lebih dari 30 dan kurang 500, sehingga penelitian ini akan menargetkan jumlah sampel 
sebesar 200 orang. Pengumpulan data akan dilakukan dengan menggunakan data primer yang diperoleh menggunakan survei melalui kuesioner secara luring yang dipilih secara acak. Target responden adalah pengguna smartphone merek xiaomi dan vivo di seluruh daerah Indonesia. Secara keseluruhan baik variabel independen, yaitu lovemark dan variabel dependen, yaitu word of mouth dan niat pembelian ulang (repurchase intention) akan merujuk pada penelitian terdahulu dari Apostolos dan Pinelopi, (2018). Demikian pula dengan dimensi penjelas dari variabel independen yaitu brand respect yang merujuk pada penelitian Apostolos dan Pinelopi, (2018).

Secara keseluruhan variabel akan diukur dengan menggunakan skala Likert tipe 5 poin. Pada pengolahan data, Item kuisoner akan menggunakan skala rating yang umum digunakan yaitu skala Likert. Jenis skala ini didesain untuk menguji seberapa kuat responden setuju dengan sebuah pernyataan yang mengikuti pola 1 = sangat tidak setuju, 2 = tidak setuju, $3=$ netral, $4=$ setuju dan $5=$ sangat setuju (Sekaran dan Bougie, 2016). Setelah data diperoleh maka akan dilakukan uji validitas dan reliabilitas alat ukur terlebih dahulu. Validitas konstruk diukur dengan menggunakan nilai average variance extracted (AVE) dimana yang nilai dari AVE seharusnya lebih besar dari 0,5 (Hair et al., 2014). Pada uji reliabilitas akan diukur dengan menggunakan Composite Reliability dan Cronbach's Alpha yang nilai diharapkan diatas 0,7 agar memberikan bukti yang memadai untuk konsistensi internal (Hair et al., 2014). Secara keseluruhan data akan diuji dan dianalisis dengan pendekatan pendekatan partial least squarestructural equation modeling (PLS-SEM).

\section{HASIL DAN PEMBAHASAN}

Penyebaran kuisoner baik secara luring maupun melalui daring sebanyak 200 responden menghasilkan data dengan tingkat pengembalian sebesar $93 \%$ atau dengan kata lain terdapat 186 kuisoner yang kembali dan terisi.

Kuisoner yang kembali tersebut terdiri dari 100 responden pengguna smartphone merek Vivo dan dan 86 responden pengguna smartphone merek Xiaomi. Responden pengguna smartphone Vivo didomonasi oleh wanita sebanyak $62 \%$ dari total responden, sedangkan pada smartphone merek Xiaomi didominasi oleh pria sebanyak $57 \%$. Karakteristik lain yang ikut menjadi warna dalam penelitian ini adalah responden yang didominasi oleh usia muda, dimana pada merek Vivo 36\% responden berada pada rentang usia 16 - 20 tahun dan sebanyak 30\% responden berada pada rentang usia 21-25 
tahun. Serupa dengan karakteristik responden pengguna merek Vivo, responden pengguna merek Xiaomi 48\% responden berada pada rentang usia 16 - 20 tahun dan di ikuti oleh rentang usia 21-25 tahun sebanyak 28\%. Selain itu, penelitian ini menggunakan lama memiliki smartphone sebagai profil responden dimana pada kedua merek baik Vivo maupun Xiaomi, didominasi oleh rentang 1 tahun - 2 tahun. Berikut ini adalah profil responden secara lengkap.

Tabel 2 Demografi Karakteristik Responden dalam Persentase

\begin{tabular}{|c|c|c|}
\hline \multirow{2}{*}{ Kategori } & \multicolumn{2}{|c|}{ Merek Smartphone } \\
\hline & Vivo & Xiaomi \\
\hline \multicolumn{3}{|l|}{ Jenis kelamin } \\
\hline Pria & $38 \%$ & $57 \%$ \\
\hline Wanita & $62 \%$ & $43 \%$ \\
\hline \multicolumn{3}{|l|}{ Usia } \\
\hline $16-20$ & $36 \%$ & $48 \%$ \\
\hline $21-25$ & $30 \%$ & $28 \%$ \\
\hline $26-30$ & $16 \%$ & $10 \%$ \\
\hline $31-34$ & $10 \%$ & $9 \%$ \\
\hline$>35$ & $8 \%$ & $5 \%$ \\
\hline \multicolumn{3}{|c|}{ Lama Penggunaan } \\
\hline$<1$ tahun & $27 \%$ & $23 \%$ \\
\hline 1 tahun -2 tahun & $44 \%$ & $34 \%$ \\
\hline 3 tahun -4 tahun & $24 \%$ & $29 \%$ \\
\hline$>4$ tahun & $5 \%$ & $14 \%$ \\
\hline
\end{tabular}

Data yang diperoleh kemudian dilakukan uji validitas convergent dengan menggunakan nilai loading factor yang harus lebih dari 0,7. Hasil uji validitas convergent baik pada merek Vivo dan Xiaomi menunjukan loading factor tiap indikator konstruk berada pada nilai diatas 0,7 yang menunjukan bahwa manifest variabel dari suatu konstruk berkorelasi tinggi. (Ghozali dan Latan, 2015).

Langkah selanjutnya adalah dengan melakukan uji reliabilitas. Pada uji reliabilitas dilakukan dengan menggunakan nilai cronbach's Alpha dimana item yang diukur dapat diterima bila nilai chonbach's alpha pada rentang 0,6 sampai 0,7 dan lebih dari 0,8 dikatakan baik (Sekaran dan Bougie, 2016). Uji reliabilitas juga menggunakan nilai composite reliability dimana nilai hasil uji diharapkan diatas 0.7 (Ghozali dan Latan, 2015). Dari hasil pengujian nampak bahwa seluruh indikator dapat dinyatakan memiliki reliabilitas internal yang cukup atau dengan kata lain instrumen yang digunakan untuk mengukur dapat dikatakan stabil dan konsisten.

Tabel 3 Hasil Uji Reliabilitas 


\begin{tabular}{lcccc}
\hline \multirow{2}{*}{ Variabel } & \multicolumn{2}{c}{ Merek Vivo } & \multicolumn{2}{c}{ Merek Xiaomi } \\
\cline { 2 - 5 } & CA & CR & CA & CR \\
\hline Brand Performance & 0.865 & 0.909 & 0.883 & 0.919 \\
\hline Brand Reputation & 0.859 & 0.904 & 0.772 & 0.853 \\
\hline Brand Respect & 0.948 & 0.954 & 0.930 & 0.939 \\
\hline Brand Trust & 0.936 & 0.948 & 0.913 & 0.931 \\
\hline Lovemark & 0.951 & 0.960 & 0.920 & 0.936 \\
\hline Positif WOM & 0.923 & 0.951 & 0.916 & 0.947 \\
\hline Repurchase Intention & 0.928 & 0.949 & 0.910 & 0.937 \\
\hline \multicolumn{2}{c}{ Sumber : Data diolah } & &
\end{tabular}

Pengujuan selanjutnya adalah uji validitas yang menggunakan nilai average variance extracted (AVE) dimana dari hasil uji validitas menunjukan nilai AVE diatas 0,5 yang bearti model memiliki validitas konvergen yang cukup. Dengan demikian dapat dikatakan bahwa instrument yang digunakan untuk mengukur konsep memiliki korelasi yang tinggi (Sekaran dan Bougie, 2016). Dengan hasil uji validitas dan reliabilitas yang cukup maka selanjutnya dapat melakukan pengujian hipotesa dengan menggunakan nilai $\mathrm{p}$ dan nilai t hitung.

Tabel 4. Hasil Uji Validitas Menggunakan Parameter AVE

\begin{tabular}{lcc}
\hline \multicolumn{1}{c}{ Variabel } & Merek Vivo & Merek Xiaomi \\
\hline Brand Performance & 0.713 & 0.741 \\
\hline Brand Reputation & 0.703 & 0.592 \\
\hline Brand Respect & 0.585 & 0.511 \\
\hline Brand Trust & 0.724 & 0.660 \\
\hline Lovemark & 0.773 & 0.678 \\
\hline Positif WOM & 0.867 & 0.857 \\
\hline Repurchase Intention & 0.824 & 0.788
\end{tabular}

Pengujian hipotesis dilakukan pada kedua merek secara terpisah. Pada merek vivo $\mathrm{t}$ tabel pada tingkat signifikansi 0,05 adalah sebesar 1,986, sehingga hipotesa diterima bila t hitung diatas $t$ tabel dan nilai $\mathrm{p}$ di bawah 0,05 . Pada hipotesa pertama, nilai $\mathrm{t}$ hitung kinerja merek (brand performance) terhadap brand respect sebesar 3.688, reputasi merek (brand reputation) terhadap brand respect sebesar 3,894, dan kepercayaan merek (brand trust) terhadap brand respect sebesar 5,644. Sedangkan seluruh nilai $\mathrm{p}$ seluruh variabel dibawah 0,05 . Dengan demikian hipotesa pertama diterima. Pada hipotesa kedua t hitung brand respect terhadap lovemark sebesar 9,846 dan nilai p dibawah 0,05. Dengan demikian dapat di katakana bahwa hipotesa kedua diterima, yaitu lovemark secara positif dijelaskan oleh brand respect. Pada hipotesa 
ketiga diterima karena nilai p dibawah 0,05 sehingga dapat dikatakan bahwa lovemark berpengaruh pada positif word of mouth dan niat pembelian ulang (repurchase intention)

Hasil pengujian hipotesa pada merek Xiaomi juga memiliki hasil serupa namun mengingat jumlah sampel yang berbeda maka t tabel yang digunakan juga berbeda yaitu 1,990. Pada hipotesa pertama, nilai t hitung kinerja merek (brand performance) terhadap brand respect sebesar 4,761, reputasi merek (brand reputation) terhadap brand respect sebesar 3.097, dan kepercayaan merek (brand trust) terhadap brand respect sebesar 3,518. Sedangkan seluruh nilai $\mathrm{p}$ seluruh variabel dibawah 0,05. Dengan demikian hipotesa pertama diterima. Pada hipotesa kedua $\mathrm{t}$ hitung brand respect terhadap lovemark sebesar 10,550 dan nilai p dibawah 0,05. Dengan demikian dapat di katakan bahwa hipotesa kedua diterima, yaitu lovemark secara positif dijelaskan oleh brand respect. Pada hipotesa ketiga diterima karena nilai $\mathrm{p}$ dibawah 0,05 sehingga dapat dikatakan bahwa lovemark berpengaruh pada positif word of mouth dan niat pembelian ulang (repurchase intention)

\section{E. SIMPULAN}

Ketiga hipotesis pada penelitian ini baik pada merek Vivo maupun pada merek Xiaomi diterima, namun jika di telisik lebih mendalam terdapat hal yang menarik dimana pada variabel pembentuk brand respect pada setiap merek berbeda. Pada merek Vivo kepercayaan merek (brand trust) memiliki pengaruh paling besar terhadap brand respect yang ditunjukan dnegan nilai t hitung yang paling besar yaitu sebesar 5,644.

Pada merek Xiaomi kinerja merek (brand performance) memiliki pengaruh paling besar terhadap brand respect yang ditunjukan dnegan nilai t hitung yang paling besar yaitu sebesar 4,761. Dengan hasil ini maka dapat di katakana bahwa lovemark pada 2 merek smartphone asal china mampu dibangun oleh brand respect, atau dengan kata lain brand respect dapat menjadi pendorong dari loyalitas melampaui alasan. Brand respect yang merepresentasikan aspek fungsional sebuah merek dibangun melalui kinerja merek (brand performance), reputasi merek (brand reputation) dan kepercayaan merek (brand trust).

Melalui penelitiandapat disimpulkan bahwa pada merek Xiaomi dan Vivo ketiga variabel, yaitu (brand performance), reputasi merek (brand reputation) dan kepercayaan merek (brand trust) berpengaruh secara positif terhadap brand respect. 51|C A P I T A L, V O L UME 4, NOMOR 1, SEPTEMBER 2020 
Walaupun demikian terdapat perbedaan dimana pada merek Vivo kepercayaan merek (brand trust) memiliki pengaruh paling besar terhadap brand respect sedangkan pada merek Xiaomi kinerja merek (brand performance) memiliki pengaruh paling besar terhadap brand respect. Hal tersebut tentu saja bukan hal mengherankan mengingat sejak semula Xiaomi sudah menunjukan sebagai merek berperforma baik dengan harga murah. Penelitian ini juga menunjukan bahwa lovemark berpengaruh terhadap niat pembelian ulang dan positif word of wouth.

\section{DAFTAR PUSTAKA}

Ahmad, Z., Jun, M., Khan, I., Abdullah, M., dan Ghauri, T. A. (2016). Examining Mediating Role of Customer Loyalty for Influence of Brand Related Attributes on Customer Repurchase Intention. Journal of Northeast Agricultural University (English Edition), Vol 23 no 2, pp 89-96.

Alto, Paul. (2019).Indonesian smartphone market Q4 2018. https://www.canalys.com/newsroom/samsung-leads-in-indonesian-smartphonesas- market-surges-ahead-to-close-2018-up-171. Diakses 12 Januari 2020

Giovanis A dan Athanasopoulou P, (2018) "Understanding lovemark brands: Dimensions and effect on Brand loyalty in high-technology products", Spanish Journal of Marketing - ESIC, Vol. 22 Issue: 3, pp. 272-294

Chetna Kudeshia dan Amresh Kumar, (2017) "Social eWOM: does it affect the brand attitude and purchase intention of brands?",Management Research Review, Vol. 40 Issue: 3 , pp.310- 330

East, R., Romaniuk, J., Chawdhary, R., dan Uncles, M. (2017). The impact of word of mouth on intention to purchase currently used and other brands. International Journal of Market Research, Vol 59 no 3, pp. 321-334.

Egham. (2019).Indonesian smartphone market Q4 2018. https://www.gartner.com/en/newsroom/press-releases/2019-02-21-gartner-saysglobal- smartphone-sales-stalled-in-the-fourth-quart. Diakses 12 Januari 2020

Filieri, R., Chen, W., dan Lal Dey, B. (2017). The importance of enhancing, maintaining and saving face in smartphone repurchase intentions of Chinese early adopters: an exploratory study. Information Technology \& People, Vol 30 no 3, pp. 629-652.

Ghozali, I., \& Latan, H. (2015). Partial Least Squares, Konsep, Teknik dan aplikasi menggunakan program SmartPLS 3.0. Badan Penerbit Undip, Undip

Hamid Hawass, H. (2013). Brand trust: implications from consumer doubts in the Egyptian mobile phone market. Journal of Islamic Marketing, Vol 4 no1, pp. 80-100. 
Maisam, S., dan Mahsa, R. D. (2016). Positive word of mouth marketing: Explaining the roles of value congruity and brand love. Journal of Competitiveness, Vol 8 no 1 , pp. 19-37.

Rahim, A., Safin, S. Z., Kheng, L. K., Abas, N., dan Ali, S. M. (2016). Factors influencing purchasing intention of smartphone among university students. Procedia Economics and Finance, Vol 37, pp. 245-253.

Roberts, K. (2005). Lovemarks: The future beyond brands. Powerhouse books.

Sekaran,U. dan Bougie, R.J. (2016). Research Methods for Business: A Skill Building Approach. John Wiley and Sons Ltd. United Kingdom.

Sweeney, J. C., Soutar, G. N., dan Mazzarol, T. (2008). Factors influencing word of mouth effectiveness: receiver perspectives. European journal of marketing, Vol 42 no 3/4, pp 344-364.

Wu, L. Y., Chen, K. Y., Chen, P. Y., dan Cheng, S. L. (2014). Perceived value, transaction cost, and repurchase-intention in online shopping: A relational exchange perspective. Journal of Business Research, Vol 67 no 1, pp 27682776.

Yang, Y. C., dan Liu, S. W. (2018). Links between switching costs, brand trust, and customer loyalty in mobile phone services. International Journal of Organizational Innovation (Online), Vol 10 no 4,pp 315-326. 